\title{
EVALUASI PROGRAM NASIONAL PEMBERDAYAAN MASYARAKAT PENGEMBANGAN INFRASTRUKTUR EKONOMI WILAYAH (PNPM-PISEW)
}

\author{
Aida Fitriani \\ Fakultas Ilmu Sosial dan Ilmu Politik Universitas Kapuas \\ Email:aidafitriani45@gmail.com
}

\begin{abstract}
Abstrak: Program Pengembangan Infrastruktur Sosial Ekonomi Wilayah (Regional Infrastructure for Social and Economic Development - RISE), yang kemudian disingkat dengan PISEW diharapkan dapat menjawab kebutuhan dalam melakukan upaya pengentasan kemiskinan, dan pengurangan tingkat pengangguran terbuka dengan juga meningkatkan kemampuan pemerintah daerah dalam melaksanakan desentralisasi dan otonomi daerah. Program PISEW dengan intervensi berupa bantuan teknis dan investasi infrastruktur dasar pedesaan, dibangun dengan berorientasi pada konsep "Community Driven Development $(C D D)$ " dan "Labor Intensive Activities (LIA)", sehingga kemudian dikategorikan sebagai salah satu program PNPM-Mandiri. Dengan demikian kemudian program PISEW dikenal dengan nama PNPM-PISEW. Indikator-indikator penelitian meliputi , evaluasi perencanaan, evaluasi pelaksanaan, evaluasipelaporan, evaluasi pemanfaatan berkelanjutan dan evaluasi penguatan kelembagaan serta dampak dari pelaksanaan kegaitan PNPM-PISEW di Kecamatan Sintang tahun 2014 baik dampak yang diharapkan maupun dampak yang tidak diharapkan.
\end{abstract}

Kata Kunci: Evaluasi Kebijakan, Evaluasi Program, Pemberdayaan masyarakat.

Prinsip dasar yang harus diperhatikan untuk melakukan evaluasi adalah dengan melihat sejauh mana masyarakat berkontribusi sebagai simpul penghambat penanganan masalah. Hal ini dimaksudkan untuk menghindarkan adanya 'penghukuman' kepada masyarakat sementara simpul penghambat penanganan bukan dimasyarakat. Berangkat dari hal tersebut, maka hal yang menjadi bahan pertimbangan dalam evaluasi bukan lagi siapa pelaku masalah tetapi siapa atau dimana simpul hambatan atas upaya penanganan masalah berada. Untuk melihat dimana simpul hambatan penanganan masalah berada dan bagaimana target progres yang diharapkan. Berikut adalah tolok ukur yang dimaksud masyarakat sebagai simpul hambatan adalah apabila masyarakat tidak memiliki kepedulian terhadap upaya penanganan masalah yang ada di kecamatan tersebut, meskipun telah dilakukan upaya untuk motivasi dan fasilitasi.

Misal: Tidak ada wakil masyarakat yang bersedia menjadi tim pemantau penanganan, atau adanya sikap apatisme untuk berpartisipasi dalam upaya penanganan masalah. Untuk kondisi demikian, perbaikan ditunjukkan dengan adanya kepedulian masyarakat dengan mengadakan musyawarah untuk tindak lanjut penanganan di berbagai tingkatan (kelompok, dusun, desa kecamatan). Simpul kemacetan di birokrasi jika birokrasi tidak mau terlibat mendukung atau bahkan menghambat upaya penanganan sehingga proses menjadi lamban atau stagnan. Atau Birokrat tidak mau melakukan sesuatu padahal berdasarkan analisa masalah akan dapat ditangani hanya jika birokrat melakukan tindakan tertentu.

Misal: Upaya penanganan akan lebih efektif jika diturunkan tim dari Bawasda dan langsung pelimpahan temuan ke kejaksaan, namun TK PNPM Mandiri terkadang tidak merespon permintaan tim dimaksud. Target progres yang harus dicapai adalah Birokrat (TK PNPM Mandiri Perdesaan) terlibat dalam upaya investigasi penunjukkan tim Audit pemerintah Dukungan pelimpahan hasil temuan ke aparat hukum dilakukan pemanggilan terhadap pelaku (terutama jika pelaku adalah aparat),. Pemberian sanksi terhadap pelaku setelah diterbitkan surat teguran yang diperlukan untuk mendukung penanganan Aparat Hukum Bahwa aparat hukum menjadi titik penghambat upaya penanganan masalah apabila masalah stagnan pada tahapan proses di aparat hukum, sementara stakeholder lain telah berusaha untuk mengadvokasi. Misal: Masalah telah dilporkan kepada kepolisian setempat, namun pelaku maupun saksi belum ada yang dipanggil. Telah dilakukan upaya monitoring dan meminta konfirmasi, tetapi tidak diperoleh keterangan yang jelas. Fasilitator Simpul hambatan ada di Fasilitator apabila dalam analisa atas hambatan penanganan, akar masalah kemacetan karena tidak adanya dukungan atau fasilitasi Fasilitator yang tidak optimal. Target progres apabila simpul kemacetan ada pada Fasilitator adalah telah dilakukan pembinaan dan atau teguran terhadap Fasilitator yang bersangkutan. Ada perbaikan kinerja Fasilitator dalam fasilitasi penanganan masalah memiliki agenda dan target penanganan. 


\section{Tahap Perencanaan}

Perencanaan dilaksanakan dengan tujuan menyusun gambaran umum masalah dan sumber daya, menyusun rencana atau program kegiatan prioritas masing-maing bidang, juga perencanaan dapat dipandang sebagai suatu proses penentuan dan penyusunan program-program kegiatan yang dilakukan, berorientasi kemasa depan, spesifik dan operasional. Aspek yang diperhatikan yang perlu diperhatikan dalam perencanaan menurut Ismail (1989 : 97) antara lain : “(a) Harus jelas tujuan dan sasaran yang ingin dicapai, (b) Realistis, artinya mengandung harapan-harapan, relevan dengan tujuan memiliki prosedur, metode dan teknik pelaksanaan yang tepat dan tetap mempertimbangkan sumber daya manusianya. (c) Harus terpadu dan sistematis, yakni memperhatikan unsur-unsur insani dan non insani, memiliki tata urutan berdasarkan skala prioritas".

\section{Tahap Pelaksanaan}

Dalam usaha menilai program, sering pula digunakan kriteria atau patokan, yaitu suatu pengertian yang dapat dijadikan dasar (standar) menilai atau mengukur. Menurut Raka (1981: 22) bahwa : "Pada dasarnya, dapat dibedakan 2 jenis kriteria, yaitu kriteria internal dan kriteria eksternal. Kriteria internal adalah standar- yang dijabarkan dari dalam rancangan program, dan kriteria eksternal adalah standar-standar yang diperoleh dari luar program. Kriteria internal suatu program dapat ditinjau dari segi konsistensi, yaitu ketepatan atau kesesuaian antara komponen yang satu dengan komponen lainnya dalam program tersebut. Kriteria eksternal suatu program, misalnya dapat ditinjau dari: (Sumber Buku Panduan umum PNPM-PISEW Tahun 2012 :15). a.

Mengidentifikasi kesesuaian antara kebijakan umum dan tujuan program. b. Pemberian pertimbangan dilakukan oleh evaluator yang dipandang ahli dalam bidangnya harus realistis atau dapat diukur.

\section{Pelaporan}

Pelaporan merupakan proses penyampaian data dan atau informasi mengenai perkembangan atau kemajuan setiap tahapan dari pelaksanaan program, kendala atau permasalahan yang terjadi, penerapan dan pencapaian dari sasaran atau tujuan program. Mekanisme pelaporan dilakukan melalui jalur struktural dan jalur fungsional konsultan, sebagai upaya untuk mempercepat proses penyampaian data dan atau informasi dari lapangan. Sistem laporan dari desa agar dibuat sesederhana mungkin, mengingat keterbatasan kemampuan administratif dari pelaksana kegiatan di desa. Materi laporan berupa data dan atau informasi yang benar dan akurat jauh lebih diutamakan daripada bentuk laporannya. Mekanisme pelaporan ini dilakukan oleh aparat terkait secara berjenjang dari Kecamatan sampai Pusat, yaitu : (Sumber buku panduan teknis sistem pelaporan PNPM-PISEW Tahun 2012:13-17).

\section{Pemanfaatan dan Keberlanjutan}

Pemanfaatan yang dimaksudkan dalam PNPM-PISEW terdiri dari 2 (dua) jenis, yaitu: pemanfaatan terhadap dokumen perencanaan yang telah disusun, dan pemanfaatan terhadap infrastruktur yang sudah dibangun. Dokumen perencanaan yang telah disusun di atas diharapkan dapat diinternalisasikan ke dalam proses perencanaan pembangunan daerah yang disusun sesuai dengan peraturan perundang-undangan yang berlaku. Optimalisasi pemanfaatan dan pengembangan infrastruktur yang sudah dibangun diharapkan dapat dilakukan oleh KPP pasca pelaksanaan kegiatan konstruksi fisik. Sedangkan keberlanjutan berkaitan dengan kegiatan program diharapkan dapat terus dikembangkan lebih lanjut oleh pemerintah daerah dan masyarakat meskipun dukungan PNPM-PISEW telah berakhir. Maksud utama dari kegiatan ini pada intinya adalah mendorong masyarakat dan pemerintah daerah untuk mempertahankan dan meningkatkan proses perencanaan pembangunan yang partisipatif dan sesuai dengan peraturan perundang-undangan yang berlaku. Sebagai suatu program, PNPM-PISEW mempunyai sasaran pelaksanaan yang mencakup sebagai berikut : (Sumber Buku Panduan umum PNPM-PISEW Tahun 2012:61). Terbangunnya infrastruktur perdesaan yang meliputi pembangunan sarana dan infrastruktur: transportasi, produksi pertanian, pemasaran pertanian, air bersih dan sanitasi, pendidikan dan kesehatan. Meningkatnya usaha ekonomi masyarakat. Terbentuknya Kawasan Strategis Kabupaten,Kelompok Usaha Masyarakat, dan institusi Kelompok Diskusi Sektor (KDS) serta menguatnya fungsi KDS di lokasi yang telah memilikinya. Meningkatnya kapasitas pemerintah dalam berperan sebagai fasilitator dalam melaksanakan pembangunan. Meningkatnya kapasitas masyarakat dalam melaksanakan pembangunan.

Adapun penerima manfaat dari PNPMPISEW mencakup antara lain: Masyarakat Desa, Lembaga Kemasyarakatan Desa (kelompok yang sudah ada seperti karang taruna, PKK, kelompok tani) dan kelompok masyarakat yang mempunyai potensi usaha di desa, danPemerintah kabupaten, kecamatan dan pemerintah desa. Fungsi tindak lanjut dalam kegiatan evaluasi program pada PNPM adalah mengarahkan dan menuntun agar suatu kegiatan yang dilakukan tetap berada dalam bingkai aturan prosedural sesuai mekanisme. Mekanisme dan hasilhasil pelaksanaan program PNPM-PISEW di tingkat kebupaten dan kecamatan diharapkan dapat terus dikembangkan lebih lanjut oleh pemerintah daerah dan masyarakat meskipun dukungan PNPM-PISEW terlah 
aberakhir. Hail ini bertujuan untuk mendorong masyarakat dan pemerintah daerah dalam mempertahankan keberlanjutan proses perencanaan pembangunan secara partisipatif. Beberapa kegiatan yang diharapkan dapat dilanjutkan di antaranya adalah proses pemilihan KSK, penyusunan MPK untuk kegiatan PSE Kabupaten, penyusunan dokumen Renstra Kecamatan, penyusunan dokumen PIK, pembentukan KDS, dan pembentukan KPP. Untuk meningkatkan keberlanjutan program, Pemda perlu melanjutkan program PNPM-PISEW dengan PNPMPISEW Mandiri dengan sumber dana berasal dari pemerintah Daerah yang dilaksanakan pasca pelaksanaan program PNPM-PISEW

\section{Dampak Yang Diharapkan}

Hasil PNPM yang diharapkan dan dapat menjadi suatu program untuk lebih menyentuh langsung ke masyrakat antara lain :(Sumber Buku Panduan Umum PNPM-PISEW 2012:11):1. Memperluas kesempatan usaha dan membuka lapangan kerja baru. Dampak signifikan terhadap kenaikan belanja rumah tangga pedesaanhasil studi di kecamatan lokasi PNPM Mandiri Pedesaan menunjukan adanya peningkatan belanja rumah tangga yang cukup besar di banding kecamatan non-program. Sasaran program yang berpihak pada orang miskin dan kesetaraan gender. Berdasarkan berbagai studi, dampak sosial dan ekonomi, PNPM Mandiri Pedesaan terbukti sukses dalam menentukan sasaran dan memberikan bantuan kepada kecamatan termiskin di Indonesia, dengan sasaran kelompok masyarakat miskin. Meningkatkan kapasitas, kinerja lokal dan kelembagaan, pembentukan model perencanaan dan pembiyaan partisipatif. Rendahnya tingkat korupsi-Audit independen terhadap PPK yang di laksanakan oleh Moors Rowland menemukan penyimpangan proyek desa ini kurang dari $1 \%$ dari total dana yang telah di salurkan. Meningkatkan akses ke pasar, puast kota, fasilits pendidikan dan kesehatan, dan sumber air bersih lebih dari 56\% desa termiskin di seluruh Indonesia. PNPM Mandiri Pedesaan (melalui PPK dan PNPM-PPK) telah mendanai lebih dari 171.466 kegiatan sarana/prasarana pedesaan di lokasi program di seluruh Indonesia. Tingginya tingkat pengembalian investasi. Penghematan biaya dalam jumlah signifikan

\section{Dampak Yang Tidak Diharapkan}

PNPM dinilai tidak banyak perperan langsung dalam pengentasan kemiskinan. Akibatnya, kelompok miskin tidak dijadikan sebagai prioritas dalam pelaksanaan program. Hal ini, terlihat dari perencanaan proyek yang tidak selalu mempertimbangkan manfaat bagi warga miskin, penargetan tenaga kerja dalam pelaksanaan proyek fisik PNPM yang tidak secara khusus menyasar warga miskin, atau keharusan swadaya bagi warga tanpa pengecualian bagi orang miskin. Pelaksanaan PNPM berpotensi dan bahkan sudah menimbulkan konflik, seperti konflik antar Desa, antara Pemerintah Desa dengan tim pelaksana kegiatan (TPK), antara TPK dengan masyarkat dan antara kelompok pribumi dengan pendatang, serta konflik pengadaan barang dan jasa. Selain terkait dengan kurangnya pemahaman tentang program, dan oleh karena itu juga kurang sosialisasi, penyebab lain dari berbagai konflik tersebut adalah kurangnya koordinasi dengan atau pelibatan pihak yang relevan dalam pelaksanaan program. Kurangnya koordinasi juga menyebabkan konflik antara Pemerintah Desa dengan TPK, sementara untuk kasus pribumi dan pendatang, potensi konflik di picu oleh kecemburuan akibat ketimpangan, yaitu daerah transmigrasi lebih maju, sementara daerah pribumi relatif tertinggal. Karena dalam PNPM disyaratkan adanya swadaya masyarakat, sering kali desa yang mendapat program PNPM adalah desa transmigrasi. Hal ini terjadi karena jalan desa transmigrasi luas dan para transmigrasi memiliki banyak tanah, sehingga ketika mereka diminta swadaya dalam bentuk tanah, mereka tidak keberatan memberikannya. Sebaliknya, di desa pribumi jalannya sempit dan warga tidak mau memberikan tanahnya yang memang sempit sehingga mereka tidak mendapatkan program fisik PNPM.

PNPM belum berhasil memperdayakan masyarakat desa karena (Sumber Tim Koordinasi PNPM-PISEW 2012:32) a. struktur kekuasaan desa yang timpang karena adanya dominasi elite desa sehingga warga miskin sangat termarginalkan; b. model permberdayaan PNPM sangat mekanistik: fasilitator hanya sekedar memastikan terlaksananya tahapan-tahapan program, tanpa adanya usaha lebih jauh untuk "menyadarkan" dan "meningkatkan kapasitas" masyarakat terkait tujuan program untuk mendorong terciptanya tata pemerintahan yang baik (partisipari, transparansi dan akuntabilitas) serta meningkatkan kemampuan ekonomi masyarakat dengan berbasis kemandirian; c. adanya ketidaksesuaian antara mekanisme program dan karakteristik budaya local: PNPM mendorong partisipasi individual dalam kegiatan maupun dalam penyelenggaraan pemerintah desa; d. sebagian fasilitator tidak berkualitas dan tidak berpengalaman, serta sering terjadinya rotasi wilayah bagi fasilitator.

\section{METODE}

Jenis penelitian yang digunakan adalah penelitian kialitatif. Informan adalah sumber utama data penelitian, yaitu yang memiliki data mengenai focus penelitian. Informan dipilih dengan teknik purposive. Teknik pengumpulan data yang dilakukan dalam penelitian ini adalah wawancara, observasi dan studi dokumentasi.Analisis data bersifat kualitatif. Menurut Bogdan dan Taylor (dalam Moleong, 1995:3)"sebagai prosedur penelitian yang menghasilkan data deskriptif berupa kata-kata tertulis atau lisan dari orang-orang 
dan prilaku yang dapat diamati”. Penelitian ini dilakukan pada Kantor Camat Sintang. Pemilihan lokasi tersebut berdasarkan pertimbangan praktis dan metodologis.

\section{HASIL PENELITIAN DAN PEMBAHASAN}

\section{Tahap Perencanaan.}

Perencanaan Program Nasional Pemberdayaan Masyarakat Pengembangan Infrastruktur Sosial Ekonomi Wilayah (PNPM PISEW) berupaya memadukan pendekatan partisipatif masyarakat dan pendekatan teknokratik pemerintah daerah. Pendekatan bawah-atas (Bottom $U p$ ) disinergikan dengan pendekatan atas-bawah (Top Down). Menurut hasil wawancara penulis dengan Camat Sintang, diketahui bahwa Perencanaan Program Nasional Pemberdayaan Masyarakat Pengembangan Infrastruktur Sosial Ekonomi Wilayah (PNPM PISEW) di Kecamatan Sintang dilaksanakan secara berjenjang. Setelah Pemerintah Kabupaten Sintang menyatakan komitmen terhadap PISEW, maka dibentuklah Tim Koordinasi PNPM-PISEW Kabupaten Sintang termasuk didalamnya Sekretariat PNPM-PISEW Kabupaten Sintang dari dinas/badan/ lembaga/kantor terkait dengan cakupan bidang PSE yang disahkan oleh Bupati.

Anggota Tim Koordinasi dan Sekretariat PNPM-PISEW disiapkan untuk diutus dalam rangka mengikuti Pelatihan Tingkat Pusat. Hasil dari Pelatihan Provinsi adalah Persiapan Orientasi dan Workshop Kabupaten Sintang untuk mempersiapkan acara Orientasi Kabupaten Sintang, baik dari sisi materi yang akan disampaikan, kebutuhan peserta yang akan diundang serta substansi acara. Kemudian, dilaksanakan Orientasi dan Workshop Kabupaten Sintang untuk mensosialisasikan kegiatan PNPMPISEW kepada pemangku kepentingan yang lebih luas, yang disertai Persiapan Tim PNPM-PISEW Kabupaten Sintang sebagai pelaku utama PISEW Kabupaten Sintang untuk menetapkan pembagian tugas dan fungsinya.

Setelah tugas dan fungsi Tim PNPM-PISEW Kabupaten Sintang ditetapkan, kemudian Sekretariat PNPM-PISEW melaksanakan Persiapan dan Pelaksanaan Lokakarya PSE Kabupaten Sintang. Persiapan yang dilakukan adalah menyusun profil singkat PSE Kabupaten Sintang, menetapkan tema lokakarya serta penjaringan makalah untuk mengisi lokakarya. Selain itu ditetapkan pula peserta lokakarya serta agenda pelaksanaan untuk memandu pelaksanaan. Sebagai tindak lanjut perencanaan di tingkat Kabupaten, di tingkat Kecamatan Sintang dilakukan Pembentukan Tim Pokja Kecamatan Sintang dan Persiapan Calon Peserta Pelatihan Provinsi. Tim Pokja Kecamatan Sintang ini terdiri atas staf Kecamatan Sintng yang ditunjuk oleh Camat sebagai pelaku utama di tingkat Kecamatan Sintang, 156 peluang dan ancaman. Dalam mensinkronkan kegiatan yang akan dilatih di tingkat provinsi bersama tim konsultan Kecamatan Sintang. Setelah dilatih di tingkat provinsi dan Orientasi di tingkat Kabupaten Sintang, kemudian dilakukan Persiapan Sosialisasi Kecamatan Sintang dan Pelatihan Fasilitator Kecamatan Sintang(FD). Persiapannya meliputi perumusan materi sosialisasi, penyebaran undangan, dan Penetapan calon FD. Kemudian, dilaksanakan acara sosialisasi kegiatan PNPM-PISEW dan Pelatihan FD dalam rangka penggalian isu PSE sebagai masukan untuk penyusunan dokumen PSE Kecamatan Sintang. Rencana kerja kegiatan di tingkat Kecamatan Sintang dijelaskan dan disepakati.

Tahap selanjutnya adalah Analisis Potensi Pengembangan Kecamatan Sintang dan Kelompok Diskusi Sektor (KDS). Kegiatan ini bertujuan untuk menggali informasi dalam rangka perumusan pengembangan sosial ekonomi Kecamatan Sintang, serta mengidentifikasi para pelaku pengembangan sosial ekonomi sesuai dengan potensi Kecamatan Sintang dalam wadah KDS. Pembentukan KDS lebih didasarkan atas kegiatan ekonomi yang dominan di Kecamatan Sintang tersebut, sebagai perencana, dan pemanfaat pembangunan. Cakupan KDS adalah hamparan kegiatan ekonomi homogen bukan batas administrasi. Kemudian, hasil analisis di atas, disampaikan pada Sosialisasi Desa se Kecamatan Sintang, yang mempunyai muatan sosialisasi program dan data pengembangan Kecamatan Sintang, Sosialisasi dan klarifikasi KDS serta Identifikasi Potensi Desa. Fasilitator Kecamatan Sintang merupakan kader yang akan mendampingi Tim Konsultan Kecamatan Sintang dalam pelaksanaan di tingkat Desa Di Kecamatan Sintang. Identifikasi Potensi merupakan upaya lebih lanjut dari pengenalan Kecamatan Sintang yang lebih rinci, sebagai dasar penetapan usulan kegiatan. Hasil Sosialisasi Kecamatan Sintang dan Analisis Potensi Pengembangan Kecamatan Sintang menjadi masukan bagi Penyusunan Profil PSE Kecamatan Sintang untuk menggambarkan kondisi PSE Kecamatan Sintang lebih komprehensif.

Pelatihan Fasilitator Kecamatan Sintang yang dilakukan setelah sosialisasi untuk mempersiapkan Fasilitator Kecamatan Sintang dalam mendampingi masyarakat dalam proses kegiatan PNPM-PISEW. Materi pelatihan ini selain teknis pelaksanaan PNPMPISEW sesuai dengan tugasnya, juga diberikan materi peningkatan kemampuan dalam memfasilitasi kegiatan dan menumbuhkan partisipasi masyarakat. Kegiatan awal Fasilitator Kecamatan Sintang adalah memfasilitasi Penjaringan Aspirasi Masyarakat (Diskusi KDS). Kegiatan ini bertujuan untuk merumuskan kegiatan-kegiatan yang menjadi kebutuhan masyarakat dalam lingkup PSE. Rumusan kegiatan adalah sesuai dengan hasil penilaian hamparan yang meliputi aspek kekuatan, kelemahan, 
antar KDS (karena setiap KDS dapat terdiri dari beberapa bagian Desa) yang kemudian dikembalikan dalam lingkup Desa Di Kecamatan Sintang, maka dilaksanakan Diskusi antar KDS dan Desa Di Kecamatan Sintang. Jaring keterkaitan (fungsi, lokasi, manfaat) antar kegiatan digunakan dalam analisis ini, sehingga menghasilkan kegiatan-kegiatan dalam lingkup Desa Di Kecamatan Sintang. Hasilnya, kemudian dilakukan Finalisasi Usulan Kegiatan Kecamatan Sintang untuk disampaikan ke Musrenbang Desa. Kemudian, di tingkat Kecamatan Sintang dilaksanakan Perumusan Renstra Kecamatan Sintang. Merupakan kegiatan analisis intergrasi pengembangan Kecamatan Sintang yang didasarkan atas Indikator Misi PSE Jangka Menengah yang disusun di tingkat Kabupaten Sintang, Potensi Kecamatan Sintang, serta Usulan Kegiatan Kecamatan Sintang dari KDS, yang kemudian dilakukan penilaian untuk menetapkan prioritas kegiatan Jangka Menengah Pembangunan Kecamatan. KDS yang dibentuk di tingkat Kecamatan Sintang, disosialisikan di tingkat Kecamatan Sintang dan diklarifikasi kebenarannya agar KDS benar-benar sesuai dengan ketentuan dan kondisi sebenarnya.

Kegiatan Identifikasi Potensi Kecamatan Sintang merupakan penilaian awal bagi tinjauan dan analisis kebutuhan dan potensi masyarakat (lokal) yang bertujuan untuk mengetahui lebih lanjut karakter Kecamatan Sintang dari perspektif masyarakat, yang meliputi aspek-aspek sosial-ekonomi masyarakat, kondisi fisik, serta hal-hal khusus lain yang perlu mendapat perhatian. Dengan mengetahui kondisi awal (kondisi eksisting) serta local knowledge maka akan dapat diketahui karakter Kecamatan Sintang tersebut, yang selanjutnya dapat memudahkan dalam menangani apabila ada permasalahan yang timbul. Pada kegiatan penilaian awal kebutuhan Kecamatan Sintang dan Desa Di Kecamatan Sintang, diharapkan teridentifikasinya isu pokok Kecamatan Sintang dan tergambarnya kondisi awal Desa Di Kecamatan Sintang. Kegiatan Pengenalan Kecamatan Sintang ini dilakukan dengan 2 (dua) metode, yaitu forum pertemuan dengan masyarakat dan kunjungan kondisi lapangan.

Penilaian Awal Kondisi Kecamatan Sintang dilakukan dengan penyusunan Instrumen Pengenalan Kondisi Awal. Fasilitator Kecamatan Sintang (FK) mempelajari Hasil Kajian Profil/Gambaran Umum Kecamatan Sintang dan menyimpulkan butir-butirnya dalam format Kecamatan Sintang serta Mempelajari Peta Orientasi Kecamatan Sintang.

Fasilitator Kecamatan Sintang kemudian membuat Rencana dan Jadwal Kerja pelaksanaan kunjungan identifikasi awal ke Desa. Fasilitator Kecamatan Sintang dapat meminta bantuan beberapa anggota Pokja Kecamatan Sintang untuk dapat mendampingi pelaksanaan kunjungan ke Desa. Jika diperlukan, FK dapat menyusun Daftar Pertanyaan (Kuesioner) atau Check-List untuk keperluan kunjungan ke Desa Di Kecamatan Sintang, serta membahasnya dengan Tim Kunjungan Lapangan (anggota Pokja danTTL). Bersama dengan TTL dan Anggota Pokja Kecamatan Sintang, FK kemudian melaksanakan kunjungan lapangan menuju Desa Di Kecamatan Sintang. Di dalam setiap kunjungan dan pengamatan lapangan yang dilakukan, diadakan beberapa pertemuan atau wawancara dengan para tokoh atau pemuka, dan masyakarat setempa.Pada akhir kunjungan Tim Kunjungan Lapangan (FK dan Pokja) melakukan perumusan terhadap isu Pokok dan Kondisi Awal setiap Desa di Kecamatan Sintang yang telah dikunjungi. Penilaian Awal Kondisi Kecamatan Sintang antara lain adalah di dalam penyusunan Rencana dan Jadwal Kerja perlu diperhatikan target waktu yang tersedia disesuaikan dengan kondisi kebiasan masyarakat setempat. Daerah pengamatan yang akan dilakukan dengan metode participatory planning ini lebih besar dari area yang umumnya diterapkan oleh metode tersebut. Karena itu, perlu diperhatikan bahwa dalam melakukan kegiatan pengamatan jangan terlalu menyeluruh, tetapi harus selektif. Walaupun demikian, jangan sampai hal-hal yang dianggap penting (masalah krusial atau kelompok kecil tertentu) terlewatkan dalam pengamatan ini. Karena daerahnya yang cukup luas (Kecamatan Sintang), maka hasil dari kegiatan ini harus dapat mengidentifikasi penampakan yang umum serta kepentingan dominan dari (kelompok) masyakarat. Langkah kegiatan ini merupakan kegiatan pertama dimana kontak dengan masyarakat secara langsung dilakukan. Karena itu, sangat penting kiranya ditekankan agar FK dapat memberikan gambaran yang benar dari maksud kunjungannya, dan mampu untuk membangkitkan interest masyarakat.

Analisis kebutuhan masyarakat dilakukan untuk menyusun suatu usulan dan prioritas kegiatan yang didasarkan atas aspirasi kebutuhan masyarakat terkait dengan kondisi sosial ekonomi di wilayahnya. Karena itu usulannya harus muncul dari masyarakat, berdasarkan pembahasan oleh masyarakat, dan hasilnya untuk masyarakat. Begitu pula halnya dengan pembahasan dan pengusulan dalam rangka kegiatan PNMP-PISEW. Pembahasan dan pengusulannya dilakukan melalui KDS dengan bimbingan FD. Tujuan kegiatan ini adalah untuk mengetahui dan memahami kegiatan perekonomian Kecamatan Sintang dalam perspektif masyarakat, serta melihat dan mengidentifikasi permasalahan, peluang dan kendalanya. Pada akhirnya berguna di dalam merumuskan masukan mengenai kebutuhan dan prioritas kegiatan lokal terkait dengan penyusunan Renstra Kecamatan Sintang. Selain itu, dari kegiatan ini diharapkan dapat: Menyempurnakan informasi awal mengenai pola kegiatan sosioekonomis penduduk, Mendapatkan hasil analisis mengenai "issues" utama dan permasalahan yang dihadapi oleh 
setiap KDS, Mengembangkan alternatif atau skenario usulan yang dilihat atau berasal dari perspektif/ aspirasi masyarakat

\section{Tahap Pelaksanaan.}

Pada pelaksanaan Program Nasional Pemberdayaan Masyarakat Pengembangan Infrastruktur Sosial Ekonomi Wilayah (PNPM PISEW), ditetapkan bahwa Program Nasional Pemberdayaan Masyarakat Pengembangan Infrastruktur Sosial Ekonomi Wilayah (PNPM PISEW) akan menyediakan prasarana dengan ketegorisasi terdiri prasarana transportasi pedesaan, penyehatan lingkungan, ekonomi produktif khususnya bidang pertanian. Dengan kebijakan ini, sangat diperlukan suatu proses penyedian prasarana dengan kualitas teknis sesuai kaidah dan spesifikasi teknis yang berlaku. Namun demikian disamping pertimbangan kualitas teknis, juga dipertimbangkan upaya pemberdayaan masyarakat dan penguatan kelembagaan daerah dimana keseluruhannya diharapkan dapat mendukung dan mempercepat proses pembangunan daerah. Dalam kerangka pembangunan daerah, dimana proses penyedian prasarana dengan kualitas yang teknis yang tinggi serta mempertimbangakannya proses pemberdayaan masyarakat dan penguatan kelembagaan daerah. Menurut Fasilitator dan pendamping tingkat kecamatan dan desa pengelompokan prasarana yang dibangun atas sifat penggunaannya adalah Prasarana yang sifatnya umum, yaitu prasarana dimana setiap orang dapat / boleh menggunakannya. Prasarana yang bersifat lokal spesifik, dimana hanya kelompok tertentu yang dapat memanfaatkan secara terusmenerus. Prasarana yang sifatnya individu, dimana hanya individu tertentu yang dapat memanfaatkannya.

Pengelompokan tersebut sangat mempengaruhi siapa yang menjadi penanggungjawab dalam proses pelestarian dan pemeliharaan prasarana tersebut, baik prasarana yang dibangun untuk melayani umum ataupun untuk melayani kelompok. Dalam kegiatan PNPM-PISEW akan melibatkan berbagai institusi, sesuai dengan komponen kegiatan yang menjadi tugas pokok dan fungsí serta kompetensi dari berbagai institusi pemerintah baik itu dipusat maupun didaerah, dan konsultan/fasilitator yang akan memberikan bantuan teknis kepada masyarakat, pemerintah pusat dan pemerintah daerah. Pada tingkat Desa Di Kecamatan Sintang, pengelola kegiatan adalah Pemerintah Desa. Kepala Desa bertanggungjawab atas pengendalian dan kelancaran kegiatan yang dilakukan oleh Kelompok Diskusi Sektor (KDS) selama tahapan perencanaan, LKD selama tahap pelaksanaan dan kelompok pemanfaatan dan pemeliharaan (KPP) pada tahap pemanfaatan dan pemeliharaan serta pemanfaatan kredit mikro oleh KUM. KDS dapat meliputi hanya satu Desa atau lebih. Pembentukan KDS difasilitasi oleh Pokja
Kecamatan Sintang dan TTL (FK dan Ttl) setelah terlebih dahulu melakukan analisa potensi unggulan dan kondisi geografis Kecamatan Sintang. Dalam pengorganisasian Program PNPM-PISEW di Kecamatan Sintang ada juga Lembaga Kemasyarakatan Desa (LKD).

Masih ditemukan kesalahan-kesalahan administrasi pada proses pencairan dana PNPMPISEW baik dari Kecamatan mupun dari Desa yang mendapat kegiatan PNPM-PISEW. Hal ini disebabkan para kepala Desa masih banyak yang kurang mau berkoordinir dengan Tim Pelaksana PNPM-PISEW dilapangan, sehingga sering terjadi keterlambatan pencairan dana karna kesalahan pada administrasi saja. LKD Di Kecamatan Sintang yaitu lembaga kemasyarakatan yang sudah ada dan diakui keberadaannya oleh masyarakat dan pemerintah Desa Di Kecamatan Sintang, seperti kelompok Perkumpulan Petani Pemakai Air (P3A), Karang Taruna, PKK, Remaja Mesjid, Remaja Gereja, dan sebagainya. Setiap LKD harus mempunyai struktur organisasi tang terdiri dari Ketua, Bendahara, Sekretaris, Tenaga Teknis, dan anggota. Pengurus Organisasi tersebut sekurang-kurangnya terdiri dari 5 (lima) orang, dengan minimal satu anggotanya adalah perempuan atau perwakilan unsur minoritas di Desa Di Kecamatan Sintang.

Dinas Pekerjaan Umum sebagai pemantau kegiatan PNPM-PISEW sekaligus sebagai penghitung seberapa jauh volume pekerjaan yang telah dilaksanakan oleh Tim Pelaksana PNPM-PISEW bersama masyarakat, apakah sesuai dengan ajuan baik dari anggaran dan tempat pelaksanaan pekerjaan. Pada kegiatan PNPM-PISEW Dinas Pekerjaan Umum diminta untuk menjadi pendamping pelaksanaan kegiatan dilapangan, karena hal ini menyangkut segi teknis kegiatan. Pengorganisasian PNPM-PISEW di Kecamatan Sintang juga melalui Kelompok Pemanfaat dan Pemelihara (KPP) yaitu organisasi yang terdiri dari unsur masyarakat yang memanfaatkan dan memelihara hasil kegiatan pembangunan prasarana di wilayah nya. KPP dibentuk dan ditetapkan melalui Musyawarah Desa yang difasilitasi oleh FK, POKJA Kecamatan Sintang dan LK. KPP disah kan oleh Kepala Desa atas sepengetahuan Camat.

\section{Pelaporan.}

Sistem pelaporan pada PNPM-PISEW dibuat berjenjang mulai dari tingkat desa, kecamatan, kabupaten, provinsi sampai ke pusat. Laporan dilakukan baik melalui jalur struktural maupun melalui jalur fungsional. Mekanisme pelaporan ini dilakukan oleh aparat terkait secara benjenjang dari Kecamatan sampai Pusat, yaitu : 
A. Jalur Struktural.

1. Camat dengan dibantu TTL dan Pokja Kecamatan menyusun laporan kemajuan pelaksanaan kegiatan yang meliputi: tahap perencanaan, pelaksanaan, dan pembangunan prasarana. Laporan disampaikan setiap bulan kepada Bupati melalui Tim Koordinasi Kabupaten.

2. PPK PISEW Kabupaten menyiapkan laporan rekapitulasi rencana penyerapan dan realisasi keuangan, kepada PMU. Laporan disampaikan sekali setahun.

3. Satker Kabupaten menyiapkan laporan kemajuan fisik berdasarkan dokumen "Sertifikasi Bulanan" untuk BLM lokasi KSK dan BLM Kecamatan dari laporan PPK PNPM-PISEW Kabupaten, PJOK KSK dan PJOK Kecamatan, Rekapitulasi laporan tersebut disampaikan kepada Bupati setiap bulan melalui Tim Koordinasi Kabupaten. Disamping itu Satker/PPK juga secara rutin melaporkan kemajuan melalui E-Mon yang ada di Kementerian Pekerjaan Umum.

4. Bupati melalui Tim Koordinasi Kabupaten dibantu Sekretariat PNPM-PISEW Kabupaten dan Satker Kabupaten menyampaikan laporan berisi rekapitulasi kemajuan pelaksanaan kegiatan, baik tahap persiapan dan perencanaan, pembangunan prasarana, maupun perencanaan tahun berikutnya, realisasi dan efektivitas penggunaan dana PAP, serta pembinaan dan koordinasi terhadap realisasi kemajuan, kepada Gubernur melalui Tim Koordinasi Provinsi. Laporan ini disampaikan 3 (tiga) bulan sekali.

5. Gubernur melalui Tim Koordinasi Provinsi menyampaikan laporan berisi rekapitulasi kemajuan pelaksanaan kegiatan, baik tahap persiapan dan perencanaan, pembangunan prasarana maupun perencanaan tahun berikutnya, realisasi dan efektivitas penggunaan dana PAP, serta pembinaan dan koordinasi terhadap realisasi kemajuan kegiatan seluruh kabupaten. Laporan ditujukan kepada Menteri terkait melalui Tim Pusat c.q PMU, Laporan ini disampaikan 3 (tiga) bulan sekali.

6. PMU menyampaikan laporan setiap bulannya kepada Tim Koordinasi Pusat melalui Sekretariat Nasional PNPM-PISEW.

B. Jalur Fungsional

1. Tingkat Kecamatan

TTL selaku tenaga pendamping di Kecamatan, membuat laporan program PNPM-PISEW berdasarkan laporan kemajuan kegiatan pembangunan prasarana oleh LKD, serta menyusun laporan kemajuan kegiatan dari pendampingan dan pengamatan terhadap pelaksanaan program
PNPM-PISEW ditingkat Kecamatan dan Desa. TTL menyampaikan laporan mingguan dan bulanan kepada ATK dan KMK dengan tembusan ke Pokja Kecamtan. Laporan bulanan disampaikan selambatlambatnya tanggal 5 (lima) bulan berikutnya. Penanggungjawab laporan adalah FK.

2. Tingkat Kabupaten

KMK dan ATK selaku tenaga pendamping di wilayah Kabupaten, menerima, mengolah, menganalisis, dan menindaklanjuti laporan yang disampaikan TTL, serta menyusun laporan kegiatan dari pendampingan dan pengamatan terhadap pelaksanaan program PNPM-PISEW ditingkat Kabupaten, Kecamatan dan Desa. Berdasarkan bahan-bahan tersebut, KMK dan ATK masing-masing menyusun laporan mingguan dan bulanan yang disampaikan kepada KMP dan KMT provinsi dengan tembuasan Sekretariat PNPM-PISEW Kabupaten. Laporan bulanan disampaikan selambat-lambatnya tanggal 7 (tujuh) bulan berikutnya.

3. Tingkat Provinsi

KMP dan KMT selaku tenaga pendamping di wilayah Provinsi dan sekaligus selaku Koordinator/Team Leader dari Konsultan Daerah, menerima, mengolah, menganalisis, dan menindaklanjuti laporan yang disampaikan KMK dan ATK, serta menyusun laporan kegiatan dari pendampingan dan pengamatan terhadap pelaksanaan program PNPM-PISEW ditingkat Provinsi, Kabupaten, Kecamatan dan Desa. Laporan KMP (bulanan) dan KMT (mingguan dan bulanan) yang disampaikan kepada PIU dan KMAP dengan tembusan Tim Koordinasi Provinsi. Laporan bulanan disampaikan selambat-lambatnya tanggal 12 (dua belas) bulan berikutnya.

4. Tingkat Pusat

KMAP menerima, mengolah, menganalisis, dan menindaklanjuti laporan yang disampaikan oleh KMP, KMT dan KMK/ ATK (baik dalam bentuk buku maupun dalam format file softcopy). Selanjutnya KMAP menyusun dan memberikan laporan kepada PMU dengan tembusan kepada Sekretariat PNPM-PISEW Nasional c.q. KPTKP. Selambat-lambatnya tanggal 25 (dua puluh lima) bulan berikutnya. KPTKP membuat analisa kebijakan pelaksanaan program secara nasional dan melakukan pengkajian terhadap perundang-undangan dan peraturan-peraturan yang terkait dengan program. Selanjutnya KPTKP memberikan laporan kepada Tim Koordinasi Pusat melalui Sektrtariat Nasional PNPM-PISEW. 


\section{Pemanfaatan dan Keberlanjutan.}

Dalam pelestarian dan kesinambuangn prasarana dan sarana yang telah dibangun, diperlukan adanya Pemanfatan dan Keberlanjutan atau sering disebut sebagai Pemanfataan dan Pemiliharaan secara optimal oleh masyarakat pengguna prasarana dengan pendampingan/pembinaan dari Pemerintah Daerah. Pasca pelaksanaan pembangunan konstruksi dibentuk Kelompok Pemanfaatan dan Pemeliharaan (KPP) sebagai wahana masyarakat dalam hal pemanfaatan dan pemeliharaan konstruksi yang telah dibangun. Karena itulah diharapkan para KPP benarbenar dapat berfungsi dalam melakukan pengoprasian dan pemeliharaannya, kedepan KPP diharapkan dapat mengembangkan infrastruktur tersebut. Hal ini penting agar dapat tercapai tujuan berikut ini, yaitu: Jaminan berfungsinya prasarana dan sarana yang telah dibangun secara berkelanjutan, guna meningkatkan kualitas hidup dan tingkat perekonomian masyarakat;Tumbuhnya kemampuan masyarakat dalam pengelolaan sumber-sumber pembiayaan untuk pemanfaatan dan pemeliharaan;Meningkatnya fungsi kelembagaan masyarakat di desa dan kecamatan dalam pengelolaan hasil kegiatan;Tumbunya rasa memiliki terhadap hasil kegiatan yang telah dilaksanakan.

Harapan yang digantungkan kepada KPP ini memerlukan pengolahan yang melibatkan berbagai pihak yang berkepentingan. Pemerintah perlu mengadakan campur tangan terhadap KPP sehingga masyarakat di pedesaan akan menjadi masyarakat yang berdaya dalam mengelola sumber daya di daerahnya. Pemanfaatan dan pemeliharaan adalah serangkaian kegiatan terencana dan sistematis yang dilakukan secara rutin maupun berkala untuk menjaga agas prasarana dan sarana tetap dapat berfungsi dan bermanfaat sesuai rencana. Pelibatan masyarakat dalam kegiatan pemanfaatan dan pemeliharan dilakukan melalui wadah KPP (Kelompok Pemanfaatan dan Pemeliharaan). Kelompok Pemanfaatan dan Pemeliharaan adalah organisasi yang terdiri dari unsur masyarakat desa yang memanfaatkan dan memelihara hasil kegiatan pembangunan prasarana di wilayahnya. Sesuai dengan Peraturan Pemerintah No. 72 Tahun 2005 tentang Desa, dalam PNPM-PISEW KPP dapat dikatagorikan kepada Lembaga Kemasyarakatan, maka pembentukan KPP difasilitasi oleh Kepala Desa dibantu oleh Fasilitator Desa (FD), Fasilitator Kecamatan dan Pokja Kecamatan melalui Masyarakat Desa. Pembentukan KPP dilakukan pada waktu proses perencanaan atau setelah penandatanganan kontrak pekerjaan dan paling lambat sebelum serah terima pekerjaan dari Lembaga Kemasyarakatan Desa (LKD) kepada Pejabat Pembuat Komitmen (PPK). Pada dasarnya KPP sebagai sebuah kelompok masyarakat, untuk keanggotaannya bersifat terbuka dan suka rela, yang terpenting adalah siapapun yang menjadi anggota harus mengikuti aturan main yang telah disepakati. Kaitannya dengan PNPM-PISEW paling tidak batasan anggota KPP sebagai berikut: Anggota KPP adalah semua warga pemanfaat prasarana yang dapat diidentifikasi yang berdomisili di sekitar areal prasarana tersebut, bias berasal dari satu desa atau antar desa. Keanggotaannya bukan perorangan tetapi keluarga. Setiap keluarga yang memanfaatkan prasarana otomatis menjadi KPP. Kelompok yang sudah ada seperti halnya Kelompok Petani Pemakai Air yang memanfaatkan fasilitas air dari saluran irigasi dapat sekaligus berfungsi sebagai kelompok pemanfaat dan pemelihara. Anggota LKD bias menjadi anggota KPP. Monitoring dan evaluasi KPP adalah proses rutin pengumpulan data dan pengukuran kemajuan KPP sehingga dapat memberikan suatu penilaian dan evaluasi terhadap kinerja KPP, serta mengidentifikasi kekuatan dan kelemahan berbagai aspek seperti aspek Organisasi, Administrasi, Keuangan dan Teknis pemeliharaan yang memungkinkan Pemerintah Daerah dapat menyempurnakan secara bertahap kualitas KPP sesuai dengan situasi, kondisi, dan kemampuan daerah. Hasil monitoring dan evaluasi digunakan untuk: Membantu memetakan dan mengidentifikasi isu dan permasalahan, kemampuan dan kapasitas KPP dalam mengelola organisasinya. Membantu dalam pengembangan program peningkatan kapasitas dan kemampuan KPP dalam pemeliharaan dan pemanfaatan infrastruktur. Memberi penguatan pada kegiatan Pelatihan KPP dan penentuan kelayakan KPP pada proses serah terima dari Pemerintah Daerah.

\section{Dampak Yang Diharapkan}

Program Nasional Pemberdayaan Masyarakat Pengembangan Infrastruktur Sosial Ekonomi Wilayah (PNPM PISEW) menekankan pada pemberdayaan melalui pendamping untuk meningkatkan kemampuan masyarakat dan memberikan keleluasaan/kesempatan kepada masyarakat dalam melakukan pilihan, memberikan kemampuan dalam bidang manajemen sehingga pelaksanaanya tepat waktu, pelaporan dilakukan dengan cepat dan pengendalian yang intensif serta mengembangkan control sosial, dimana semua dinilai sangat bermanfaat bagi masyarakat. Selain implementasi program PNPM dalam penelitian ini juga menelaah dampak implementasi kebijakan tersebut. Oleh karena itu perlu diuraikan dampak implementasi program PNPM di Kecamatan Sintang baik yang bersifat positif maupun yang bersifat negative. Dampak yang diharapkan dari pelaksanaan program PNPM di Kecamatan Sintang secara umum adalah mendukung pembangunan ekonomi regional, pemerataan pembangunan dan pemberdayaan masyarakat desa serta mengurangi kemiskinan di pedesaan. Secara khusus dampak yang diharapkan dari program PNPM di Kecamatan Sintang adalah meningkatkan kemampuan masyarakat dan 
kelembagaan masyarakat dalam mengelola pembangunan; menciptakan lapangan pekerjaan; memperkuat kemampuan aparat dalam memfasilitasi masyarakat dan mengelola pembangunan; menyediakan prasarana perdesaan; menyediakan prasarana kesehatan; serta menyediakan prasarana ekonomi produktif.

\section{Dampak Yang Tidak Diharapkan}

Selain dampak positif dalam implementasi program PNPM di Kecamatan Sintang juga berpeluang melahirkan dampak negative berupa terjadinya konflik sosial (vertikal dan horisontal). Hal ini disebabkan kebijakan PNPM pada umum terjadinya konflik dari pihak-pihak yang terlibat di dalamnya. program PNPM-PISEW juga berpotensi melahirkan kecemburuan antara satu wilayah/desa yang mendapat program PNPM-PISEW dengan desa lainnya yang tidak dilaksanakan program PNPM. Gambaran tersebut diatas tentu saja bukan untuk dikeluhkan dan menjadi apatis, tetapi justru harus menjadi peringatan kepada kita semua pengelola pembangunan termasuk Pemerintah Daerah untuk mempercepat target penurunan angka kemiskinan di daerah. PNPM-PISEW sebagai salah satu kegiatan dibawah bendera 'pengentasan kemiskinan' harus berusaha keras berkontribusi kearah tersebut. Jawabannya berpulang pada kita semua, pada komitmen kita semua, baik sebagai Pemerintah Pusat, Pemerintah Daerah, dunia usaha maupun masyarakat untuk bertekad demi kesejahteraan rakyat yang sekarang masih menderita akibat belenggu kemiskinan.

\section{KESIMPULANDAN REKOMENDASI KEBIJAKAN}

Pembangunan, pemanfaatan dan pengembangan prasarana, dapat disimpulkan prasarana yang dibangun oleh kegiatan PNPMPISEW di Kecamatan Sintang Tahun 2014 secara keseluruhan dapat berfungsi dan dapat dimanfaatkan oleh masyarakat. khususnya untuk jalan tanah dapat berfungsi secara maksimal pada waktu musim panas, sedangkan untuk jalan sirtu dan rabat beton dapat berfungsi memperlancar lalu lintas darat masyarakat. Jembatan dan air bersih dapat dimanfaatkan dengan baik juga walaupun ada beberapa sumur bor yang kurang volume airnya pada saat musim kemarau yang lebih dari satu minggu. Untuk posyandu dan tambahan ruang kelas serta meubelir semua berfungsi sesuai dengan kapasitasnya. Berdasarkan indikator penguatan kelembagaan pemerintahan daerah dapat disimpulkan Kegiatan Pelatihan Aparatur Desa dilakukan sebelum dimulainya pelaksanaan kontruksi fisik Pelatihan yang dilakukan antara lian: pelatihan tingkat provinsi, pelatihan tingkat kabupaten, sosialisasi dan pelatihan tingkat kecamatan, pelatihan fasilitator Desa, sosialisasi dan pelatihan tingkat Desa. Dari indikator pemberdayaan masyarakat dapat disimpulkan LKD dimasing-masing Desa di Kecamatan Sintang terlibat aktif baik dari mulai perencanaan sampai pada proses pelaksanaan kegiatan PNPM-PISEW.

Dampak kegiatan PNPM-PISEW di Kecamatan Sintang Tahun 2014 dapat disimpulkan dampak yang diharapkan dari kegiatan PNPMPISEW adalah meningkatkan kemampuan masyarakat dan kelembagaan masyarakat dalam mengelola pembangunan; menciptakan lapangan pekerjaan; memperkuat kemampuan aparat dalam memfasilitasi masyarakat dan mengelola pembangunan; menyediakan tempat dibangunnya baik itu prasarana perdesaan, kesehatan, dan ekonomi produktif khusus dalam bidang pertanian. Sedangkan dampak yang tidak diharapkan adalah menimbulkan konflik sosial (vertikal dan horisontal). Yaitu adanya kecemburuan sosial antara satu wilayah/Desa yang mendapatkan kegiatan PNPM-PISEW dengan Desa lainnya yang belum mendapatkan kegiatan PNPMPISEW.

Berdasarkan hasil Evaluasi Program Nasional Pemberdayaan Masyarakat Pengembangan Infrastruktur Ekonomi Wilayah (PNPM-PISEW) di Kecamatan Sintang Tahun 2014, disarankan agar dalam perencanaan kegiatan PNPM-PISEW untuk berikutnya supaya masyarakat bisa ambil peran dalam penentuan tempat kegiatan sehingga kegiatan PNPMPISEW bisa merata di perdesaan khususnya di Kecamatan Sintang. Dalam mengatasi dampak yang tidak diharapkan (konflik) maka sebelum kegiataan dilaksanakan dilakukan pendekatan secara persuasip terhadap masyarakat dan kelembagaan setempat, sehingga dapat diketahui oleh Tim Pelaksana apa yang diharapkan oleh masyarakat tersebut. Sehingga pada perencanaan untuk tahun berikutnya dapat meminimalisir konflik antar masyarakat desa yang tidak diharapkan dan tidak perlu terjadi. 
161 Fokus, Jilid 12, Nomor 2, Maret 2014, hlm. 152-161

\section{DAFTAR PUSTAKA}

Arief Zainudin, 2000. Pengertian Monitoring, Supervisi, Evaluasi dan Pelaporan Pendidikan Luar Sekolah; Jakarta Universitas Terbuka.

Bappenas, 2000. Program Pembangunan Nasional, http://www.bappenas.go.id/bap ind.html (31 Januari 2013).

Buku Panduan Umum Tim Koordinasi PNPMPISEW Pusat.

Buku Petunjuk Teknis Operasional PNPM Mandiri, 2012.

Bambang Widianto. Sekretaris Eksekutif TNP2K. Buku Pedoman Pelaksanaan Program PNPM. Jakarta.

Joni Raka. 1981. Penilaian Program Pendidikan. P3G. Jakarta.

Ismail, 1989. Fungsi Perencanaan dalam Lingkup Manajemen; Jakarta.

Moleong, LJ. 1995. Metodologi Penelitian Kualitatif, Bandung: PT. Remaja Rosdakarya
Tambunan. 1982. Inventarisasi Barang dan Jasa.Jakarta.

Tim Koordinasi Program Pengembangan Kecamatan. 2007. Tugas dan Tanggung Jawab Pelaku PPK. Jakarta. Departemen Dalam Negeri.

Tim Koordinasi Program Pengembangan Kecamatan. 2007. Jenis dan Proses Pelaksanaan Kegiatan-Kegiatan PPK. Jakarta. Departemen Dalam Negeri.

Tim Koordinasi Program Pengembangan Kecamatan. 2007. UPK, Penyaluran Dana dan Administrasi Kegiatan PPK. Jakarta. Departemen Dalam Negeri.

Buku Panduan Umum Tim Koordinasi PNPMPISEW Pusat.

Buku Petunjuk Teknis Operasional PNPM Mandiri, 2012.

Data Dari Kecamatan Sintang Kegiatan PNPMPISEW Tahun 2014. 